Prof. Corneliu-Liviu POPESCU

\title{
Decorarea personalului medico-sanitar implicat în combaterea pandemiei SARS-CoV-2 / COVID-19
}

\section{Decorating the medical staff involved in combating the SARS-CoV-2 I COVID-19 pandemic}

\section{Cuvinte cheie}

Pandemie. Stare de urgență. Personal medico-sanitar. Decorare.

\section{Key words}

Pandemic. State of emergency. Medical staff. Decoration.

\section{Rezumat}

Similar situațiilor care au existat în timp de război, personalul medicosanitar implicat în combaterea pandemiei în timpul stării de urgență trebuie decorat, ca expresie a recunoștinței Națiunii și a Statului.

\section{Abstract}

Similar to the situations that existed during wars, the medical personnel involved in combating the pandemic during the state of emergency must be decorated, as an expression of the gratitude of the Nation and the State.

1. În situații excepționale, precum conflicte armate, tulburări interne grave sau catastrofe naturale care amenință existența normală a societății și viața persoanelor, o Națiune mare, prin adevărații ei oameni de stat, știe să îi onoreze, inclusiv post-mortem, pe aceia care s-au sacrificat ori au contribuit major la apărarea oamenilor și a societății.

O formă importantă prin care Națiunea și Statul, prin reprezentanții săi la 
cel mai înalt nivel, își exprimă în mod solemn recunoștința față de cei merituoși este acordarea de decorații. În România, sediul general al materiei este reprezentat de Legea nr. 29/2000 privind sistemul național de decorații al României ${ }^{1}$.

2. În cadrul sistemului național de decorații al României regăsim, în categoria decorațiilor pe domenii de activitate, Ordinul Meritul Sanitar și Medalia Meritul Sanitar.

Reglementarea specială pentru aceste decorații este dată de Legea nr. 539/2003 privind Ordinul Meritul Sanitar și Medalia Meritul Sanitar².

3. Conform art. 2 alin. (1) din Legea nr. 539/2003, Ordinul Meritul Sanitar se poate acorda pentru "merite deosebite în domeniul ocrotirii sănătății populației, în combaterea unor epidemii, în domeniul cercetării și practicii medicale, în creșterea prestigiului științei medicale românești și în asigurarea asistenței medicale", iar potrivit art. 2 alin. (2) din aceea lege Medalia Meritul Sanitar se poate acorda persoanelor care "s-au distins prin activități meritorii în toate domeniile curente medicale". Condițiile sunt detaliate în art. 14 din anexa nr. 1 și în art. 12 din anexa nr. 2 la această lege.

Se observă că ipoteza combaterii epidemiilor (pandemiilor) este avută în vedere expres de text.

4. Ratione personae, același articol dă vocație pentru decorare cu Ordinul Meritul Sanitar persoanelor cu studii superioare (medici, medici dentiști, farmaciști, biochimiști, biologi și chimiști din sistemul sanitar, psihologi, asistenți medicali și mamoși cu studii superioare etc.), în timp ce personalul medico-sanitar fără studii superioare (asistenți medicali și mamoși fără studii superioare, asistenți de farmacie, laboranți, infirmieri, paramedici, brancardieri, ambulanțieri, registratori medicali, personal de prim ajutor etc.) are vocație la decorare cu Medalia Meritul Sanitar.

5. Atribuția de a conferi decorații este dată de art. 94 ("Alte atribuții") lit. a) corelat cu art. 100 ("Actele Președintelui") alin. (2) din Constituție Președintelui României și Primului-Ministru împreună, fiind exercitată prin decret care necesită contrasemnare.

Ordinul Meritul Sanitar și Medalia Meritul Sanitar se conferă la 
propunerea individuală de decorare făcută de ministrul de resort, avizată de Cancelaria Ordinelor din cadrul Administrației Prezidențiale, în temeiul art. 4 alin. (2) lit. c) și art. 5 din Legea nr. 29/2000 și al art. 6 alin. (1) și (2) din Legea nr. 539/2003. Președintele României are competența să confere și din proprie inițiativă Ordinul Meritul Sanitar (cu excepția gradului de Mare Ofițer) și Medalia Meritul Sanitar, în proporție de 1\% din numărul total stabilit prin lege pentru fiecare grad sau clasă a fiecărei decorații, potrivit art. 4 alin. (3) din Legea nr. 29/2000 și al art. 6 alin. (3) și (2) din Legea nr. 539/2003.

Pentru cetățenii români, conferirea Ordinului Meritul Sanitar se face începând cu gradul de Cavaler, iar conferirea gradelor superioare (Comandor, Ofițer și Mare Ofițer) se face după efectuarea stagiului, pentru existența unor noi merite; similar, Medalia Meritul Sanitar se acordă începând cu clasa a III-a art. 11, art. 12 alin. (1), art. 14, art. 20 și art. 22 din Legea nr. 29/2000 și art. 9 art. 11 din anexa nr. 1 și art. 7 - art. 9 din anexa nr. 2 la Legea nr. 539/2003.

6. Există un număr maxim de decorații privind Ordinul Meritul Sanitar (cu excepția celor conferite străinilor și a celor conferite ca decorație militară de război) și Medalia Meritul Sanitar (cu excepția cu excepția celor conferite străinilor, a celor conferite ca decorație militară de război și a claselor a III-a și a II-a), stabilit de art. 8 și art. 11 din Legea nr. 539/2003, precum și de art. 2 din anexa nr. 1 și de art. 2 din anexa nr. 2 la lege.

Repartiția numărului maxim de decorații care se acordă anual se realizează de Cancelaria Ordinelor, în limita locurilor vacante, în temeiul art. 7 alin. (1) din Legea nr. 539/2003.

7. Din interpretarea art. 74 din Legea nr. 29/2000 (extrem de neinspirat plasat în capitolul privind dispoziții tranzitorii și finale) rezultă că orice decorație - deci, și Ordinul Meritul Sanitar sau Medalia Meritul Sanitar - se poate conferi și post-mortem.

În cazul conferirii unei decorații post-mortem, este evident că aceasta nu este vizată de și nu se include în limita numerică maximă a decorațiilor pe tipuri / grade / clase.

8. În opinia noastră, în timpul stării de urgență determinate de pandemia SARS-CoV-2 / COVID-19, în afară de dotarea cu aparatură medicală, medicamente și echipamente de protecție, cu posibilitatea de angajare de 
personal suplimentar și cu suplimentarea drepturilor de natură salarială acordate personalului medico-sanitar, ar fi fost mai mult decât necesară - deja de mult timp - conferirea unor decorații (sau, după caz, înaintarea în grad / clasă, pentru cei care au fost deja anterior decorați, a) personalului medicosanitar de toate categoriile implicat în combaterea, sub orice formă, a pandemiei.

În primul rând, credem că s-ar fi impus imediat decorarea post-mortem, cu Ordinul Meritul Sanitar sau cu Medalia Meritul Sanitar, după caz, a membrilor personalului medico-sanitar (la știința noastră ocupând funcții de medic, asistent medical și ambulanțier) decedați ca urmare a infectării cu SARS-CoV-2, în exercitarea atribuțiilor de serviciu, deci ca urmare a COVID19.

În al doilea rând, credem că este necesară decorarea membrilor personalului medico-sanitar infectat cu SARS-CoV-2, deci care au fost / sunt bolnavi de COVID-19, dacă infectarea s-a produs ca urmare a exercitării profesiei sau meseriei (dovada urmând a fi făcută cu toate mijloacele de probă, inclusiv cu prezumții).

În sfârșit, apreciem că este potrivită decorarea membrilor personalului medico-sanitar cu merite deosebite în prevenirea răspândirii virusului SARSCoV-2 și/sau în tratarea și/sau vindecarea bolnavilor de COVID-19.

9. Suntem conștienți că propunerile noastre pot ridica două obiecțiuni, una de natură juridică, iar cealaltă din perspectiva oportunității.

Chestiunea juridică vizează respectarea numărului total maxim de decorații și a cotei anuale. O eventuală obiecțiune nu este însă insurmontabilă, nimic neîmpiedicând Guvernul să adopte o ordonanță de urgență prin care să prevadă că Ordinul Meritul Sanitar și Medalia Meritul Sanitar, acordate în legătură cu combaterea pandemiei de SARS-CoV-2, nu întră în calculul plafoanelor totale și anuale (așa cum se întâmplă cu decorațiile conferite ca decorațiile militare de război). Tot atât de bine, Guvernul poate institui, tot prin ordonanță de urgență, o decorație specială legată de combaterea acestei epidemii, fără a prevedea vreun plafon numeric sub aspectul acordării ei.

Problema de oportunitate ar putea fi ridicată de utilitariști: suntem în plină pandemie, guvernanții au de rezolvat chestiuni mult mai importante și mai urgente decât cea a decorațiilor, de care se pot eventual ocupa după ce pandemia va fi trecut; plus că mai bine dăm bani pe materiale de protecție 
decât pe decorații. Un asemenea (posibil) argument ar fi ignobil. $\mathbf{O}$ Națiune mare și oamenii de stat adevărați care conduc o Națiune mare se îngrijesc constant și de moralul celor implicați în acțiunile de apărare a oamenilor și a societății. Oamenii de stat adevărați nu au așteptat să treacă războiul pentru a decora ostașii, ci s-au dus pe front, în linia întâi, și au înmânat decorațiile personal, chiar sub focul inamicului.

10. De altfel, în timpul actualei stări de urgență, instituite prin Decretul Președintelui României nr. 195/2020 privind instituirea stării de urgență pe teritoriul României ${ }^{3}$ și prelungite prin Decretul Președintelui României nr. 240/2020 privind prelungirea stării de urgență pe teritoriul României ${ }^{4}$, Președintele României s-a ocupat fără probleme de chestiunea decorațiilor:

- pe data de 01.04.2020, prin Decretul nr. 224/2020 privind retragerea unei decorațiii ${ }^{5}$, Președintele României a retras ${ }^{6}$ Ordinul Meritul Sanitar în grad de Cavaler conferit Spitalului de Urgență "Sfântul loan cel Nou" din Suceava prin Decretul nr. 205/2019 privind conferirea Ordinului Meritul Sanitar ${ }^{7}$;

- pe data de 28.04.2020, prin Decretul nr. 244/2020 privind conferirea Ordinului Meritul Cultural în grad de Mare Ofițer ${ }^{8}$, prin Decretul nr. 245/2020 privind conferirea Ordinului și Medaliei Meritul Cultural $^{9}$, prin Decretul nr. 246/2020 privind conferirea Ordinului Virtutea Aeronautică în grad de Cavaler $^{10}$, prin Decretul nr. 247/2020 privind conferirea Ordinului Virtutea Aeronautică în grad de Cavaler $^{11}$ și prin Decretul nr. 248/2020 privind conferirea Ordinului National Pentru Merit în grad de Cavaler ${ }^{12}$, Președintele României a conferit decorații Ateneului Național din lași și unor persoane lucrând la Biblioteca Militară Națională (Ordinul Meritul Cultural sau Medalia Meritul Cultural), respectiv unor unități militare (Ordinul Național Pentru Merit sau Ordinul Virtutea Aeronautică).

Departe de noi gândul de a nega meritele celor decorați, dar este evident că dacă Președintele României și Primul-Ministru și-au găsit timp să semneze, respectiv să contrasemneze decrete de decorare pentru merite fără legătură cu activitatea de combatere a pandemiei, ar fi fost normal să-și găsească timp și pentru semnarea unor decrete de decorare (în câteva cazuri, din păcate, post-mortem) a personalului medico-sanitar.

Ar fi fost acte de veritabili oameni de stat propunerea (de ministrul Sănătății), contrasemnarea (de Primul-Ministru) și semnarea (de Președintele României a) unor decrete de decorare (repetăm, inclusiv din 
păcate post-mortem) a membrilor personalului medico-sanitar implicați, uneori cu prețul vieții, în combaterea pandemiei.

Ar fi fost un gest măreț, de reprezentant al Națiunii și al Statului, ca Președintele României să înmâneze personal membrilor familiilor decorațiile conferite post-mortem, respectiv să înmâneze personal, în spitale, decorațiile conferite personalului medico-sanitar. Șeful de stat ar fi trebuit să se ridice la înălțimea rolului său de simbol al Statului și al Națiunii și să exprime acum, în timpul pandemiei, recunoștința Națiunii și a Statului pentru personalul medico-sanitar.

29.04.2020

Materialul a fost publicat în revista online a Facultăţii de Drept, $\underline{\text { AUBD- }}$ Forum Juridic nr. 1/2020.

\footnotetext{
${ }^{1}$ Republicată în Monitorul Oficial al României, partea I, nr. 118/18.02.2014.

2 Publicată în Monitorul Oficial al României, partea I, nr, 926/23.12.2003.

${ }^{3}$ Publicat în Monitorul Oficial al României, partea I, nr. 212/16.03.2020.

${ }^{4}$ Publicat în Monitorul Oficial al României, partea I, nr. 311/14.04.2020.

5 Publicat în Monitorul Oficial al României, partea I, nr. 274/01.04.2020, cu rectificare publicată în Monitorul Oficial al României, partea I, nr. 299/09.04.2020.

${ }^{6} \mathrm{Nu}$ face obiectul prezentei analize legalitatea decretului de retragere a decorației, prin raportare la dispozițiile art. 51 - art. 54 din Legea nr. 29/2000 (cum o persoană juridică nu poate fi condamnată penal la o pedeapsă privativă de libertate, singurul temei legal al retragerii decorației îl constituie săvârșirea de fapte dezonorante care aduc prejudicii membrilor ordinului, iar aceste fapte trebuie judecate de Consiliul de onoare al Ordinului, cu respectarea dreptului persoanei decorate vizate de a fi invitată să participe la judecata Consiliului de onoare și de a se apăra).

${ }^{7}$ Publicat în Monitorul Oficial al României, partea I, nr. 264/05.04.2019.

${ }^{8}$ Publicat în Monitorul Oficial al României, partea I, nr. 344/28.04.2020.

${ }^{9}$ Publicat în Monitorul Oficial al României, partea I, nr. 344/28.04.2020.

${ }^{10}$ Publicat în Monitorul Oficial al României, partea I, nr. 344/28.04.2020.

${ }^{11}$ Publicat în Monitorul Oficial al României, partea I, nr. 344/28.04.2020.

12 Publicat în Monitorul Oficial al României, partea I, nr. 344/28.04.2020.
} 